\title{
Adopsi Teknologi Internet of Things pada Startup Industri $\mathrm{F} \& \mathrm{~B}$

\author{
Adoption of Internet of Things Technology in the F\&B Industry Startup Supply Chain
}

\author{
Margo Purnomo ${ }^{1}$, Erna Maulina ${ }^{2}$, Aulia Rizki Wicaksono ${ }^{3}$, Muhamad Rizal $^{4}$ \\ ${ }^{1,2,3,4}$ Doctoral Program, Faculty of Social and Political Sciences - Business Administration, \\ Padjajaran University \\ E-mail: 1purnomo@unpad.ac.id, 2erna.maulina@unpad.ac.id, ${ }^{3}$ aulia18023@unpad.ac.id, \\ ${ }^{4}$ m.rizal@unpad.ac.id
}

\begin{abstract}
Abstrak
Efisiensi di sepanjang rantai pasokan industri F \& B yang terintegrasi dengan kemajuan teknologi telah mendorong penerapan sistem ketertelusuran produk dalam bentuk pemanfaatan Internet of Things (IoT). tujuan dari penelitian ini adalah untuk menyelidiki adopsi IoT di pada Startup Industri F\&B di Jawa Barat-Indonesia. Data dianalisa dengan menyebarkan kuesioner terhadap 30 Startup Industri F\&B di Jawa Barat dengan menggunakan analisis Stuctural Equation Modeling (SEM) menggunakan aplikasi AMOS. Hasil penelitian menunjukkan bahwa sebagian besar Startup Industri F\&B di Jawa Barat menunjukkan tingkat adopsi IoT yang cukup dalam mengelola proses produksi produk F\&B mereka.
\end{abstract}

Kata kunci: Internet of Things, Startup, Teknologi, industri F\&B

\begin{abstract}
Efficiency along the the $F \& B$ industry that is integrated with technological advances has driven the application of a product traceability system in the form of utilizing the Internet of Things (IoT). The purpose of this study is to investigate the adoption of IoT in the F\&B Industry Startup Supply Chain in West Java-Indonesia. Data were analyzed by distributing questionnaires to 30 $F \& B$ Industry Startups in West Java using Stuctural Equation Modeling (SEM) by AMOS. The results showed that most of the F\&B Industry Startups in West Java showed a sufficient level of IoT adoption in managing the production process of their $F \& B$ products.
\end{abstract}

Keywords: Internet of Things, Startup, Technologies, F\&B industry

\section{PENDAHULUAN}

Bisnis food and beverages menjadi salah satu bisnis yang banyak diminati oleh masyarakat, karena selain menghasilkan keuntungan yang tinggi, makanan juga menjadi kebutuhan pokok bagi setiap orang. Jadi, dimanapun dan kapanpun masyarakat akan membutukan makanan sebagai sumber pokok kehidupan [1]. Selain faktor yang menguntungkan dari bisnis makanan, faktor lain juga mendorong pengusaha menggeluti bisnis makanan adalah terjadinya pergeseran pola hidup di masyarakat apalagi ditambah dengan kondisi pandemi yang membatasi masyarakat untuk keluar rumah, sehingga mereka memilih untuk memesan makanan melalui media online.Begitu juga dengan pesatnya perkembangan ekonomi digital semakin memudahkan masyarakat dalam menggunakan fasilitas teknologi yang ada.

Dengan kondisi yang ada maka Startup bidang makanan dan minuman menjadi salah satu bisnis yang menjanjikan. Hal ini membuat jumlah pelaku bisnis makanan dan minuman semakin meningkat dari tahun ke tahun. Namun, mempertahankan bisnis makanan dan minuman tidak mudah, sehingga para pelaku bisnis atau Startup F\&B perlu membuat strategi dalam menjaga jumlah pengunjung mereka. Seperti halnya bisnis di bidang yang lain, salah satu cara yang dapat dilakukan oleh para pelaku bisnis F\&B untuk menjaga atau bahkan meningkatkan 
jumlah konsumen mereka adalah dengan mengadopsi teknologi yang salah satunya adalah Internet of Things.

IoT adalah bagian dari TIK yang ditandai dengan hal-hal cerdas dan perpaduan teknologi dan interaksi di seluruh domain fisik, digital, dan biologis [2] yang memungkinkan revolusi industri. IoT membantu memangkas biaya implementasi [3], meningkatkan kinerja rantai pasokan [4], meningkatkan kuantitas dan kecepatan data [5]. Selain itu adopsi teknologi seperti Internet of Things ini sangat penting bagi perusahaan salah satunya dalam meningkatkan penanganan produk di sepanjang rantai pasokan bisnis [6-7]. Teknologi ini juga membantu perusahaan untuk melakukan jual beli barang secara online dan mengurangi biaya pemrosesan informasi dan komunikasi dalam manajemen internal maupun antar perusahaan di sepanjang rantai pasokan [8].

Teknologi seperti Internet of Things ini mampu mengurangi biaya operasi, menurunkan penjualan, dan biaya pembelian sambil meningkatkan pangsa pasar serta meningkatkan hubungan dengan mitra dan pelanggan. Terlepas dari berbagai keuntungan mengadopsi teknologi di antara para pemain rantai pasokan, studi empiris yang mengukur tingkat adopsi diperlukan untuk menyelidiki situasi atau fenomena yang ada. Ada banyak cara untuk mengukur tingkat adopsi di berbagai industri. Misalnya, [9] membahas manfaat dan hambatan dalam mengukur tingkat adopsi di kalangan UKM makanan terhadap sistem jaminan kualitas. Sementara [2] mengukur tingkat adopsi di kalangan UKM terhadap IR 4.0 dengan mempelajari faktor-faktor seperti biaya rendah, akses mudah, dan tekanan teman sebaya. [8] dalam penelitiannya membahas adopsi organisasi informasi dan teknologi digital dengan menggunakan tiga teori utama yaitu Theory Diffusion of Innovation (DOI), Theory of Reasoned Action (TRA), dan Technology Acceptance Model (TAM). TAM, diyakini adalah penentu niat individu untuk mengadopsi teknologi tertentu. Dua variabel yaitu persepsi kemudahan penggunaan (PEOU) dan persepsi kegunaan (PU) dimasukkan dalam TAM. Perceived ease of use (PEOU) menjelaskan sejauh mana seorang individu percaya bahwa menggunakan sistem tertentu akan bebas dari upaya fisik dan mental sementara persepsi kegunaan (PU) menjelaskan sejauh mana seorang individu percaya bahwa menggunakan sistem tertentu akan meningkatkan kemampuannya. atau kinerja pekerjaannya [10$11]$.

Sementara [12], [13] dan [8] menyoroti aspek pengetahuan yang diadaptasi dari DOI sebagai elemen fundamental dalam implementasi inovasi atau sesuatu atau yang baru. Sedangkan [14] menggunakan Teori DOI dan kerangka TOE untuk mengukur tingkat adopsi Iot ini dan hasil penelitian ini digunakan oleh [15] yang juga menganalisa adopsi IoT dengan menggunakan tujuh variabel yang terdiri dari: Kesiapan teknologi, kompatibilitas, kompleksitas, dukungan manajemen eksekutif, ukuran perusahaan, dukungan peraturan, dan masalah keamanan, dan faktor yang bergantung adalah niat untuk mengadopsi. Dukungan regulasi, salah satu dari tujuh konstruksi independen adalah konteks lingkungan. Ukuran perusahaan dan dukungan manajemen eksekutif adalah konteks organisasi. Kesiapan teknologi adalah konteks teknologi. Kompleksitas dan Kompatibilitas, dua konstruksi adalah konteks inovasi dan kemudian kami memiliki masalah keamanan. Beberapa atribut diambil dari teori DOI sementara beberapa diambil dari kerangka TOE. Sementara penelitian yang dilakukan oleh [16] menyatakan bahwa adopsi IoT ditentukan dari tiga dimensi yaitu teknologi, organisasi, dan lingkungan. Dari indetifikasi yang maka, maka kerangka konseptual yang dapat dibuat dalam penelitian ini merujuk pada penelitian [14] dan [15] yang dapat dilihat pada gambar 1 berikut 


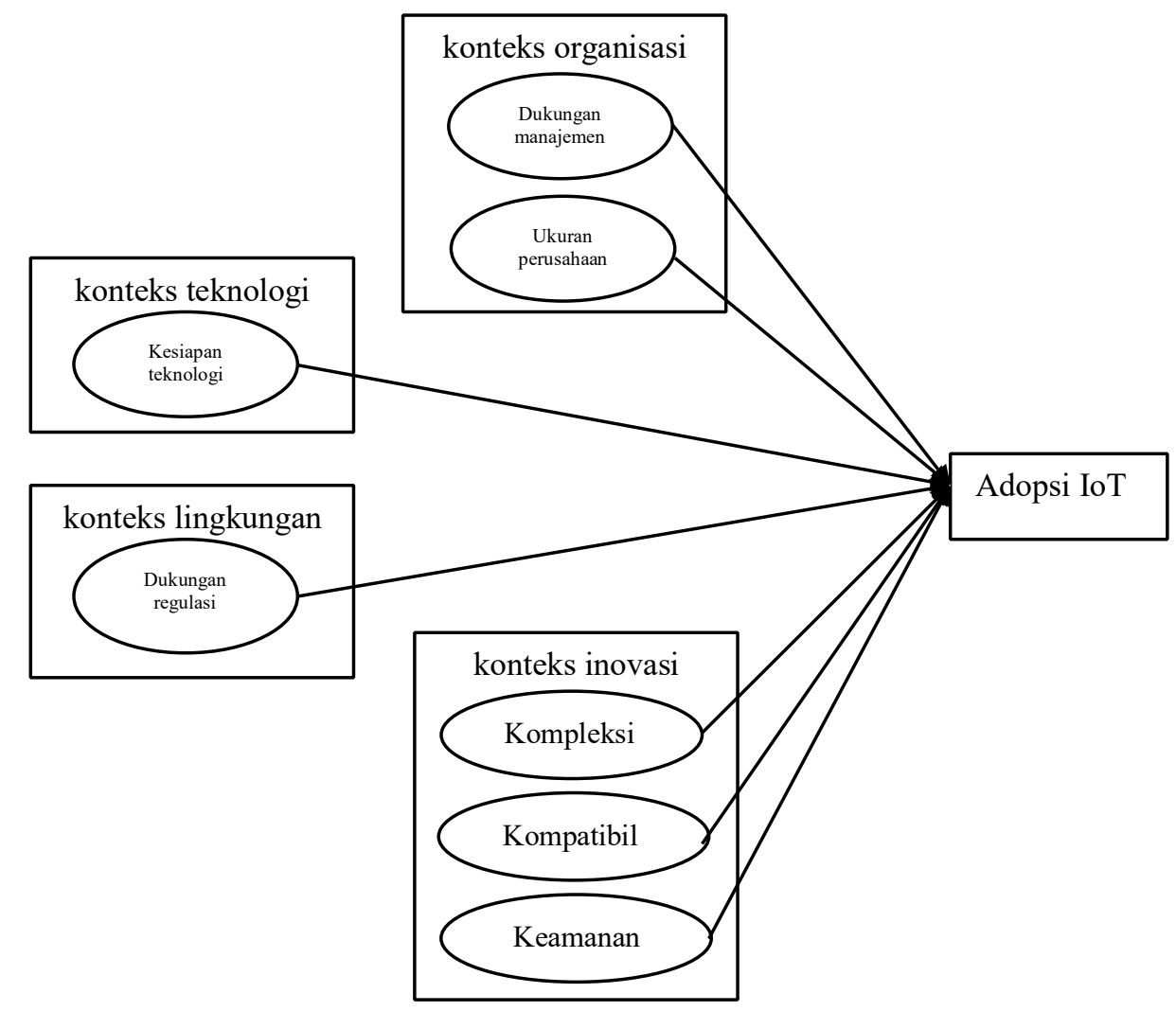

Gambar 1 Kerangka Konseptual Penelitian

Adapun penggunaan dimensi Kesiapan teknologi, kompatibilitas, kompleksitas, dukungan manajemen eksekutif, ukuran perusahaan, dukungan peraturan, dan keamanan terhadap adopsi IoT ini diperkuat dengan beberapa penelitian yang menyatakan bahwa kesiapan teknologi berpengaruh terhadap adopsi IoT $[14,17,15]$, kompatibilitas berpengaruh terhadap adopsi IoT [14-16, 18-19], kompleksitas berpengaruh terhadap adopsi IoT [14-16, 19], dukungan manajemen eksekutif berpengaruh terhadap adopsi IoT [14-16], ukuran perusahaan berpengaruh terhadap adopsi IoT [14-16.20], dukungan peraturan berpengaruh terhadap adopsi IoT [14-15, 19, 21], keamanan berpengaruh terhadap adopsi IoT [14-15, 22-28]

\subsection{Sumber dan prosedur data}

\section{METODE PENELITIAN}

Penelitian ini menggunakan metode kuantitatif dengan pendekatan verifikatof. Adapun sumber data yang digunakan adalah dari data skunder dan data primer. Data primer diperoleh dari hasil kuesioner yang diberikan kepada pemilik/pimpinan Startup F\&B di Jawa Barat. Sedangkan data sekunder diperoleh dari studi pustaka dan jurnal pendukung maupun internet. Metode pengumpulan data yang digunakan dalam penelitian ini, yaitu kuesioner dan observasi.

\subsection{Populasi dan Sampel}

Populasi terdiri dari pemilik/pimpinan Startup F\&B di Jawa Barat. Dengan menggunakan simple random sampling, dikarenakan ini merupakan pilot project maka data dikumpulkan melalui kuesioner yang disebarkan pada 30 pemilik/pimpinan Startup F\&B di Jawa Barat.

\subsection{Pengukuran}

Penelitian ini menggunakan satu variabel terikat utama (Adopsi IoT), tujuh variabel bebas (Kesiapan teknologi, kompatibilitas, kompleksitas, dukungan manajemen eksekutif, ukuran perusahaan, dukungan peraturan, dan keamanan). Responden diminta untuk menunjukkan tingkat 
persetujuan mereka dengan satu item pada skala Likert atau skala 5 poin $(1=$ sangat tidak setuju, $2=$ tidak setuju, $3=$ netral, $4=$ setuju, $5=$ sangat setuju).

\subsection{Analisis Data}

Untuk menguji hipotesis dilakukan dengan menggunakan analisis Structural Equation Modeling (SEM) menggunakan aplikasi AMOS. Adapun tahapan pengujian analisis dengan menggunakan Structural Equation Modeling (SEM) adalah merujuk pada 7 tahapan sebagai berikut: a) Pengembangan Model Teoritis (melalukan identifikasi secara teoretis terhadap permasalahan penelitian), b) Pengembangan Diagram Alur (model teoritis yang telah dibangun digambarkan dalam sebuah diagram alur, yang akan mempermudah untuk melihat hubungan kausalitas yang ingin diuji), c) Konversi diagram alur ke dalam persamaan struktural dan model pengukuran (dilakukan secara otomatis oleh program SEM yang tersedia), d) Memilih matriks input dan estimasi model (menggunakan input data yang hanya menggunakan matriks varians/kovarians atau matriks korelasi untuk keseluruhan estimasi yang dilakukan), e) Menilai identifikasi model struktural (Dalam satu model sangat mungkin memiliki banyak solusi, sehingga dipilih solusi yang sesuai. Pemilihan solusi yang sesuai itu yang sering disebut dengan masalah identifikasi), f) Mengevaluasi kriteria goodness of fit (dilakukan pengujian terhadap kesesuaian model melalui telaah terhadap berbagai kriteria goodness of fit) dan terakhir $\mathrm{g}$ ) Interpretasi dan modifikasi model (menginterpretasikan model dan memodifikasi model bagi model-model yang tidak memenuhi syarat pengujian yang dilakukan)

\subsection{Hasil}

\section{HASIL DAN PEMBAHASAN}

Pengujian hipotesis yang dilakukan dengan uji Structural Equation Modeling (SEM) dari variabel eksogen (Kesiapan teknologi, kompatibilitas, kompleksitas, dukungan manajemen eksekutif, ukuran perusahaan, dukungan peraturan, dan keamanan) dan variabel endogen (adopsi IoT) dapat dilakukan dengan menggunakan AMOS 24 diperoleh hasil SEM yang ditunjukkan pada Gambar 1.

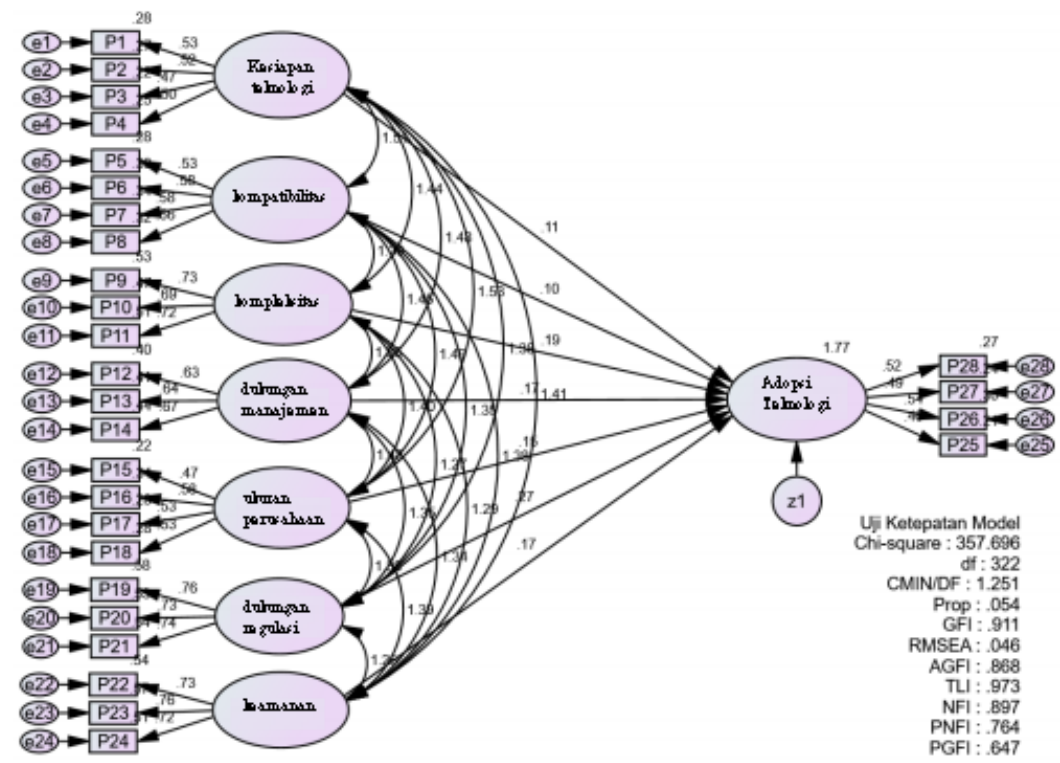

Gambar 2 Hasil Analisis Structural Equation Modeling (SEM)

Selain hasil analisis Structural Equation Modeling (SEM), data ini dukung dengan hasil evaluasi uji kecocokan model yang dapat dilihat pada tabel 1 berikut 
Tabel 1 Hasil uji kecocokan model

\begin{tabular}{|c|c|c|c|}
\hline Goodness of Fit & Nilai Kritis & Hasil Estimasi & Keterangan \\
\hline Chi-square & Diharapkan Kecil & 157,696 & Fit \\
\hline Probability & $\geq 0,05$ & 0,054 & Fit \\
\hline CMIN/DF & $<2$ & 1,251 & Fit \\
\hline GFI & $\geq 0,90$ & 0,911 & Fit \\
\hline RMSEA & $\leq 0,05$ & 0,046 & No \\
\hline AGFI & $\geq 0,90$ & 0,868 & Fit \\
\hline TLI & $\geq 0,90$ & 0,973 & No \\
\hline NFI & $\geq 0,90$ & 0,897 & Fit \\
\hline PNFI & $0,60-0,90$ & 0,764 & No \\
\hline PGFI & Diharapkan Tinggi & 0,647 & \\
\hline
\end{tabular}

Berdasarkan tabel 1 diatas diketahui bahwa hasil evaluasi Goodnes of fit secara overall didapatkan tujuh nilai estimasi yang fit, maka model penelitian tersebut dinyatakan fit (baik). Kemudian dilakukan pengujian hipotesis yang dilakukan berdasarkan nilai Critical Ratio (CR) dan tingkat signifikansi dari suatu hubungan kausalitas dengan ouput data diolah dengan SEM sebagai berikut:

Tabel 2 Hasil Pengujian Hipotesis

\begin{tabular}{|c|c|c|c|c|c|}
\hline Variabel & Variabel & Estimasi & S.E. & C.R. & P \\
\hline Adopsi IoT & kesiapan teknologi & .158 & .031 & 5.111 & .021 \\
\hline Adopsi IoT & kompatabilitas & .115 & .021 & 5.594 & .001 \\
\hline Adopsi IoT & kompleksitas & .160 & .023 & 6.972 & .026 \\
\hline Adopsi IoT & dukungan manajemen & .158 & .023 & 6.818 & .024 \\
\hline Adopsi IoT & ukuran perusahaan & .234 & .039 & 6.032 & .036 \\
\hline Adopsi IoT & dukungan peraturan & .160 & .024 & 6.760 & .032 \\
\hline Adopsi IoT & keamanan & .260 & .036 & 7.306 & .039 \\
\hline
\end{tabular}
berikut:

Dari hasil pengujian hipotesis pada tabel 2 diatas dapat diberikan penjelasan sebagai

\section{Hipotesis 1}

Dengan menggunakan analisis SEM, parameter estimasi untuk pengaruh Kesiapan teknologi terhadap adopsi IoT pada Startup F\&B di Jawa Barat menunjukkan nilai CR sebesar 5.111 lebih besar dari 1,98 dengan probabilitas sebesar 0,021 lebih kecil dari 0,05. Sehingga menolak H0 dan menerima $\mathrm{H} 1$ dengan demikian Kesiapan teknologi berpengaruh positif dan signifikan terhadap adopsi IoT pada Startup F\&B di Jawa Barat.

Hipotesis 2

Dengan menggunakan analisis SEM, parameter estimasi untuk pengaruh kompatibilitas terhadap adopsi IoT pada Startup F\&B di Jawa Barat menunjukkan nilai CR sebesar 5.594 lebih besar dari 1,98 dengan probabilitas sebesar 0,001 lebih kecil dari 0,05 . Sehingga menolak H0 dan menerima H1 dengan demikian kompatibilitas berpengaruh positif dan signifikan terhadap adopsi IoT pada Startup F\&B di Jawa Barat.

\section{Hipotesis 3}

Dengan menggunakan analisis SEM, parameter estimasi untuk pengaruh kompleksitas terhadap adopsi IoT pada Startup F\&B di Jawa Barat menunjukkan nilai CR sebesar 6.972 lebih besar dari 1,98 dengan probabilitas sebesar 0,026 lebih kecil dari 0,05 . Sehingga menolak H0 dan menerima H1 dengan demikian kompleksitas berpengaruh positif dan signifikan terhadap adopsi IoT pada Startup F\&B di Jawa Barat.

Hipotesis 4

Dengan menggunakan analisis SEM, parameter estimasi untuk pengaruh dukungan manajemen eksekutif terhadap adopsi IoT pada Startup F\&B di Jawa Barat menunjukkan nilai CR sebesar 6.818 
lebih besar dari 1,98 dengan probabilitas sebesar 0,024 lebih kecil dari 0,05. Sehingga menolak $\mathrm{H} 0$ dan menerima H1 dengan demikian dukungan manajemen eksekutif berpengaruh positif dan signifikan terhadap adopsi IoT pada Startup F\&B di Jawa Barat.

\section{Hipotesis 5}

Dengan menggunakan analisis SEM, parameter estimasi untuk pengaruh ukuran perusahaan terhadap adopsi IoT pada Startup F\&B di Jawa Barat menunjukkan nilai CR sebesar 6.032 lebih besar dari 1,98 dengan probabilitas sebesar 0,036 lebih kecil dari 0,05. Sehingga menolak H0 dan menerima $\mathrm{H} 1$ dengan demikian ukuran perusahaan berpengaruh positif dan signifikan terhadap adopsi IoT pada Startup F\&B di Jawa Barat.

Hipotesis 6

Dengan menggunakan analisis SEM, parameter estimasi untuk pengaruh dukungan peraturan terhadap adopsi IoT pada Startup F\&B di Jawa Barat menunjukkan nilai CR sebesar 6.760 lebih besar dari 1,98 dengan probabilitas sebesar 0,032 lebih kecil dari 0,05. Sehingga menolak H0 dan menerima $\mathrm{H} 1$ dengan demikian dukungan peraturan berpengaruh positif dan signifikan terhadap adopsi IoT pada Startup F\&B di Jawa Barat.

\section{Hipotesis 7}

Dengan menggunakan analisis SEM, parameter estimasi untuk pengaruh keamanan terhadap adopsi IoT pada Startup F\&B di Jawa Barat menunjukkan nilai CR sebesar 7.306 lebih besar dari 1,98 dengan probabilitas sebesar 0,039 lebih kecil dari 0,05. Sehingga menolak H0 dan menerima H1 dengan demikian keamanan berpengaruh positif dan signifikan terhadap adopsi IoT pada Startup F\&B di Jawa Barat.

Hasil pengujian hipotesis dirangkum pada Tabel 3 berikut ini

Tabel 3 Rangkuman Hasil Hipotesis

\begin{tabular}{|c|l|c|}
\hline Hipotesis & \multicolumn{1}{|c|}{ Pernyataan } & Hasil \\
\hline H1 & $\begin{array}{l}\text { Kesiapan teknologi berpengaruh positif dan signifikan terhadap } \\
\text { adopsi IoT }\end{array}$ & diterima \\
\hline H2 & $\begin{array}{l}\text { kompatibilitas berpengaruh positif dan signifikan terhadap adopsi } \\
\text { IoT }\end{array}$ & diterima \\
\hline H3 & $\begin{array}{l}\text { kompleksitas berpengaruh positif dan signifikan terhadap adopsi } \\
\text { IoT }\end{array}$ & diterima \\
\hline H4 & $\begin{array}{l}\text { dukungan manajemen eksekutif berpengaruh positif dan signifikan } \\
\text { terhadap adopsi IoT }\end{array}$ & diterima \\
\hline H5 & $\begin{array}{l}\text { ukuran perusahaan berpengaruh positif dan signifikan terhadap } \\
\text { adopsi IoT }\end{array}$ & diterima \\
\hline H6 & $\begin{array}{l}\text { dukungan peraturan berpengaruh positif dan signifikan terhadap } \\
\text { adopsi IoT }\end{array}$ & diterima \\
\hline H7 & keamanan berpengaruh positif dan signifikan terhadap adopsi IoT & diterima \\
\hline
\end{tabular}

\subsection{Pembahasan}

Berdasarkan hasil analisis data maka dapat diketahui bahwa Kesiapan teknologi, kompatibilitas, kompleksitas, dukungan manajemen eksekutif, ukuran perusahaan, dukungan peraturan, dan keamanan terhadap adopsi IoT pada Startup F\&B di Jawa Barat yaitu bahwa hasil analisis menunjukkan bahwa variabel Kesiapan teknologi berpangaruh signifikan dan positif terhadap adopsi IoT pada Startup F\&B di Jawa Barat. Hasil ini mencerminkan semakin tinggi Kesiapan teknologi yang terdapat pada Startup F\&B di Jawa Barat tersebut maka semakin tinggi tingkat adopsi IoT pada Startup F\&B di Jawa Barat. Hasil pebelitian ini sesuai dengan penelitian terdahulu yang dilakukan oleh $[14,17,15]$. Hal ini dapat dilihat bahwa sebuah Startup F\&B yang perusahaannya dengan infrastruktur teknologi dan karyawan dengan pengetahuan dan keterampilan TI yang diperbarui memiliki tingkat kesiapan teknologi yang lebih tinggi dan dengan demikian lebih mungkin untuk mengadopsi IoT. Perusahaan semacam ini berada dalam posisi yang baik untuk mengadopsi IoT. 
Kemudian dari hasil analisis menunjukkan bahwa variabel kompatibilitas berpangaruh signifikan dan positif terhadap adopsi IoT pada Startup F\&B di Jawa Barat. Hasil ini mencerminkan semakin tinggi kompatibilitas yang terdapat pada Startup F\&B di Jawa Barat tersebut maka semakin tinggi tingkat adopsi IoT pada Startup F\&B di Jawa Barat. Hasil pebelitian ini sesuai dengan penelitian terdahulu yang menyatakan bahwa kompatibilitas berpengaruh terhadap adopsi IoT [14-16, 18-19]. Hal ini dikarenakan kompatibilitas menjelaskan tingkat yang menyatukan inovasi dengan praktik atau sistem nilai saat ini. Tingkat mengadopsi perubahan sebanding dengan tingkat kompatibilitas; oleh karena itu, semakin tinggi kompatibilitasnya, semakin cepat adopsinya. Begitu juga variabel kompleksitas berpangaruh signifikan dan positif terhadap adopsi IoT pada Startup F\&B di Jawa Barat. Hasil ini mencerminkan semakin tinggi kompleksitas yang terdapat pada Startup F\&B di Jawa Barat tersebut maka semakin tinggi tingkat adopsi IoT pada Startup F\&B di Jawa Barat. Hasil pebelitian ini tidak sesuai dengan penelitian terdahulu yang menyatakan bahwa kompleksitas berpengaruh terhadap adopsi IoT [14-16, 19]. Kompleksitas dalam adopsi IoT adalah tingkat kesulitan persepsi adopsi dan integrasi IoT. Perencanaan dan Pemilihan dari berbagai gadget IoT menambah tingkat kerumitan [29] walaupun Kompleksitas tidak cocok untuk adopsi IoT, terutama ketika tidak ada karyawan yang terampil di banyak lingkungan yang kompleks

Kemudian untuk variabel dukungan manajemen eksekutifi berpangaruh signifikan dan positif terhadap adopsi IoT pada Startup F\&B di Jawa Barat. Hasil ini mencerminkan semakin tinggi dukungan manajemen eksekutif yang terdapat pada Startup F\&B di Jawa Barat tersebut maka semakin tinggi tingkat adopsi IoT pada Startup F\&B di Jawa Barat. Hasil pebelitian ini sesuai dengan penelitian terdahulu yang menyatakan bahwa dukungan manajemen eksekutif berpengaruh terhadap adopsi IoT [14-16]. Dukungan manajemen eksekutif memegang fungsi penting dalam adopsi IoT karena memimpin penyatuan layanan, berbagi sumber daya dan proses rekayasa ulang. Tanpa pengaruh dan bantuan manajemen eksekutif, perusahaan kemungkinan akan menolak adopsi IoTIoT.

Begitu juga variabel ukuran perusahaan berpangaruh signifikan dan positif terhadap adopsi IoT pada Startup F\&B di Jawa Barat. Hasil ini mencerminkan semakin tinggi ukuran perusahaan yang terdapat pada Startup F\&B di Jawa Barat tersebut maka semakin tinggi tingkat adopsi IoT pada Startup F\&B di Jawa Barat. Hasil pebelitian ini sesuai dengan penelitian terdahulu yang menyatakan bahwa ukuran perusahaan berpengaruh terhadap adopsi IoT [14-16, 20]. Perusahaan besar memiliki lebih banyak manfaat daripada yang kecil karena mereka memiliki lebih banyak sumber daya dan dapat mengambil ancaman yang lebih signifikan terkait dengan adopsi inovasi. Perusahaan kecil, meskipun lebih mudah beradaptasi, akan tetapi mereka tidak memiliki sumber daya atau pengetahuan yang memadai untuk siap mengadopsi teknologi baru.

Hasil analisis menunjukkan bahwa variabel dukungan peraturan berpangaruh signifikan dan positif terhadap adopsi IoT pada Startup F\&B di Jawa Barat. Hasil ini mencerminkan semakin tinggi dukungan peraturan yang terdapat pada Startup F\&B di Jawa Barat tersebut maka semakin tinggi tingkat adopsi IoT pada Startup F\&B di Jawa Barat. Hasil pebelitian ini sesuai dengan penelitian terdahulu yang menyatakan dukungan peraturan berpengaruh terhadap adopsi IoT [14$15,19,21]$. Peraturan pemerintah negara dapat mempengaruhi adopsi IoT oleh perusahaan. Namun regulasi IoT masih terus berkembang. Jika dan setiap kali pemerintah memberlakukan kepatuhan kebijakan IoT dengan sejumlah besar uang yang harus dibayar oleh perusahaan yang tidak mematuhi, beberapa perusahaan ingin mengadopsi IoT

Kemudian hal yang sama untuk variabel keamanan berpangaruh signifikan dan positif terhadap adopsi IoT pada Startup F\&B di Jawa Barat. Hasil ini mencerminkan semakin tinggi keamanan yang terdapat pada Startup F\&B di Jawa Barat tersebut maka semakin tinggi tingkat adopsi IoT pada Startup F\&B di Jawa Barat. Hasil pebelitian ini sesuai dengan penelitian terdahulu yang menyatakan keamanan berpengaruh terhadap adopsi IoT [14-15, 22-28]. Hal ini dikarenakan Ada risiko keamanan dan hal-hal yang memengaruhi adopsi IoT. Ada masalah seperti celah keamanan, privasi, dan masalah keamanan yang memengaruhi adopsi IoT. 


\section{KESIMPULAN DAN SARAN}

Hasil dan pembahasan pada bab sebelumnya menunjukkan bahwa Kesiapan teknologi, kompatibilitas, kompleksitas, dukungan manajemen eksekutif, ukuran perusahaan, dukungan peraturan, dan keamanan dapat digunakan untuk mengevaluasi tingkat tingkat adopsi IoT pada Startup F\&B di Jawa Barat. Berdasarkan hasil pengujian hipotesis, dapat disimpulkan bahwa tingkat adopsi pada Startup F\&B di Jawa Barat dipengaruh secara singnifikan oleh Kesiapan teknologi, kompatibilitas, kompleksitas, dukungan manajemen eksekutif, ukuran perusahaan, dukungan peraturan, dan keamanan. Sehingga disarankan bagi pengembangan teknologi informasi pada Startup F\&B di Jawa Barat untuk lebih memperhatikan Kesiapan teknologi, kompatibilitas, kompleksitas, dukungan manajemen eksekutif, ukuran perusahaan, dukungan peraturan, dan keamanan. Penelitian lebih lanjut masih perlu dilakukan dengan menambahkan variabel lainnya yang memiliki pengaruh langsung terhadap penggunaan dan penerimaan sebuah teknologi khususnya adopsi IoT pada Startup F\&B maupun aplikasi teknologi lainnya ataupun dilakukan pada unit atau lokasi penelitian lainnya.

\section{UCAPAN TERIMA KASIH}

Terima kasih yang sebesar-besarnya Penulis ucapkan kepada Universitas Padjajaran selaku pihak yang mendukung kegiatan penelitian ini dari awal hingga dapat terselesaikan dengan baik. Penulis juga mengucapkan terima kasih kepada Rektor Universitas Padjajaran serta semua pihak yang turut membantu baik secara langsung maupun tidak langsung dalam proses kegiatan penelitian ini.

\section{DAFTAR PUSTAKA}

[1] W. Ayodya, Kursus Singkat Usaha Rumah Makan Laris Manis. Jakarta: PT. Elex Media Komputindo, 2007

[2] R.Nainy, Industry 4.0, (June), 1-37, 2017

[3] Z. Li, G. Liu, L. Liu, X. Lai, \& G. Xu, IoT-based tracking and tracing platform for prepackaged food supply chain. Industrial Management \& Data Systems, 117(9), 19061916, 2017

[4] Y. Zhang, L. Zhao, \& C. Qian, C. Modeling of an IoT-enabled supply chain for perishable food with two-echelon supply hubs. Industrial Management \& Data Systems, 117 (9), 1890-1905, 2017

[5] G.C. Parry, S. A. Brax, R. S. Maull, \& I. C. L. Ng, Operationalising IoT for reverse supply: the development of use-visibility measures. Supply Chain Management: An International Journal, 21 (2), 228-244, 2016

[6] N.H. Kamarulzaman dan R.W. Eglese, The Potential Use of E-Procurement in the Malaysian Palm Oil Industry Supply Chain, Pertanika J. Soc. Sci. \& Hum. 21 (S): 95 - 108, 2013

[7] W. Tan, W. Xu, F. Yang, L. Xu, \& C. Jiang, A framework for service enterprise workflow simulation with multi-agents cooperation. Enterprise Information Systems, 7(4), 523-542, 2013

[8] S. Molinillo dan A. Japutra, Organizational adoption of digital information and technology: a theoretical review, The Bottom Line. 30. 10.1108/BL-01-2017-0002. 2017

[9] P. Karipidis, K. Athanassiadis, S. Aggelopoulos, \& E. Giompliakis, Factors affecting the adoption of quality assurance systems in small food enterprises. Food Control. 20(2): 998, 2009 
[10] A. Kesharwani and S.S. Bisht, The impact of trust and perceived risk on Internet banking adoption in India, International Journal of Bank Marketing 30(4):303-322, 2012

[11] V. Dang dan T.L. Pham, An empirical investigation of consumer perceptions of online shopping in an emerging economy: Adoption theory perspective, Asia Pacific Journal of Marketing and Logistics 30(2), 2018.

[12] H.R. Ibrahim dan M.Z.H. Mokhtarudin, Fraudulent quality labelling: case of halal labelling. China-USA Business Review, 9 (9), 41-70, 2010

[13] H. Ahmad Tarmizi , N. H. Kamarulzaman, I. A. Latiff, \& A. A.Rahman, Factors influencing readiness towards halal logistics among food- based logistics players in Malaysia. UMK Procedia, 1(October 2013), 42-49, 2014,

[14] T. Oliveira, M. Thomas, \& M. Espadanal, Assessing the determinants of cloud computing adoption: An analysis of the manufacturing and services sectors. Information \& Management, 51, 497-510. doi:10.1016/j.im.2014.03.006, 2014

[15] O.B. Olushola, Factors affecting IoT adoption, IOSR Journal of Computer Engineering (IOSR-JCE) Volume 21, Issue 6, Ser. I (Nov - Dec 2019), PP 19-24, 2019

[16] C. Arnold dan K.I. Voigt, Determinants of Industrial Internet of Things Adoption in German Manufacturing Companies, International Journal of Innovation and Technology Management, doi: 10.1142/S021987701950038X, 2017

[17] R. Martins, T. Oliveira, \& M. A. Thomas, An empirical analysis to assess the determinants of SaaS diffusion in firms. Computers in Human Behavior, 62, 19- 33. doi:10.1016/j.chb.2016.03.049, 2016

[18] A. Haddud, A. DeSouza, A.Khare, \& H. Lee, Examining potential benefits and challenges associated with the Internet of Things integration in supply chains. Journal of Manufacturing Technology Management, 28(8), 1055-1085.doi:10.1108/jmtm-05-20170094, 2017

[19] L. Ng dan S. Wakenshaw, The Internet-of-Things: Review and research directions. International Journal of Research in Marketing, 34(1), 3-21. doi:10.1016/j.ijresmar.2016.11.003, 2017

[20] M. Carcary, \& E. Doherty, \& G. Conway, The adoption of Cloud computing by Irish SMEs - An exploratory study. Electronic Journal of Information Systems Evaluation.. 17. 3-14., 2014

[21] V. Krotov, The Internet of Things and new business opportunities. Business Horizons, 60(6), 831-841. doi:10.1016/j.bushor.2017.07.009, 2017

[22] M. Ahlmeyer \& A. M. Chircu, Securing the Internet of things: A review. Issues in Information Systems, 17(4), 21-28, 2016

[23] A. Balte, A. Kashid, \& B. Patil, Security issues in internet of things (IoT): A survey. International Journal of Advanced Research in Computer Science and Software Engineering, 5(4), 450-455, 2015

[24] S. A. Kumar, T. Vealey, \& H. Srivastava, Security in internet of things: Challenges, solutions, and future directions. 2016 49th Hawaii International Conference on System Sciences (HICSS). doi:10.1109/hicss.2016.714, 2016

[25] J. SathishKumar \& R. D. Patel, A survey on Internet of Things: Security and privacy issues. International Journal of Computer Applications, 90(11), 20-26. doi:10.5120/15764-4454, 2014

[26] R.H. Weber, Internet of things: Privacy issues revisited. Computer Law \& Security Review, 31(5), 618-627. doi:10.1016/j.clsr.2015.07.002, 2015 
[27] B.D. Weinberg, G. R. Milne, Y. G. Andonova, \& F. M. Hajjat, Internet of Things: Convenience vs. privacy and secrecy. Business Horizons, 58(6), 615-624. doi:10.1016/j.bushor.2015.06.005, 2015

[28] Y. Yuchen, W. Longfei, Y. Guisheng, L. Lijie, \& Z. Hongbin. A survey on security and privacy issues in internet-of-things. IEEE Internet of Things Journal. 4(5), 1250-1258, 2017

[29] R. Y. Zhong, , X. Xu, \& L. Wang, IoT-enabled smart factory visibility and traceability using laser-scanners. Procedia Manufacturing, 10, 1-14. doi:10.1016/j.promfg..07.103, 2017 